\title{
Ruminal degradability of agro-industrial fruit residues
}

\section{Degradabilidade ruminal de resíduos da agroindústria de frutas ${ }^{1}$}

\author{
Alexandre Paula Braga ${ }^{2 *}$; Antonia Vilma de Andrade Ferreira Amâncio \\ Josemir de Souza Gonçalves²; Liz Carolina da Silva Lagos Cortes Assis²; \\ Cicília Maria Silva de Souza ${ }^{4}$ Isaac Sydney Alves da Silva Maia \\ Danillo Glaydson Farias Gerra ${ }^{3}$
}

\begin{abstract}
The aim of this study was to evaluate the chemical composition and ruminal degradability of the dry matter (DM), crude protein (CP) and neutral detergent fiber (NDF) of fruit residues. Three fistulated sheep were held collectively in a pen, and fed daily with the studied residues in a diet consisting of canarana grass (Echinochloa pyramidalis) and a concentrate of corn and soybeans. The animals were allowed an adjustment period of seven days. The residues were dried in the sun, crushed in a forage machine, sorted using a 4.0-mm sieve, and incubated for 3, 6, 12, 24, 48, 72, and $96 \mathrm{~h}$ using nonwoven bags (weight $60 \mathrm{~g} / \mathrm{m}^{2}, 14 \times 12 \mathrm{~cm}^{2}$ ). Chemical analyses of the residues were performed using a randomized block experimental design with split plots. The cherimoya and tamarind residues showed the highest concentrations of CP $(12.66 \%$ and $11.79 \%)$ the ether extract of cherimoya residue was the highest at $22.30 \%$ stands out the sour soup residue. The cashew and guava residues showed the highest levels of lignin (22.13 and $18.34 \%$ ). The effective degradability of DM for the pineapple and tamarind residues to a passage rate of $5 \% / \mathrm{h}$ were $53.04 \%$ and $42.61 \%$, respectively. The guava, cherimoya, and cashew residues showed lower values at $19.16 \%, 26.86 \%$, and $29.21 \%$, respectively. The cherimoya, guava and pineapple residues showed the highest values of potential degradability for $\mathrm{CP}$ at $87 \%, 81 \%, 86.02 \%$ and $90.94 \%$, respectively, with an average effective degradability of $50.0 \%$ at the rate of $5 \% / \mathrm{h}$. The pineapple $(35.38 \%)$ and tamarind residues $(34.49 \%)$ showed higher values of the effective degradability of NDF at a passage rate of $5 \% / \mathrm{h}$. Among the studied residues, the pineapple residue showed the greatest potential for use in animal feed based on chemical composition and rates of degradability.
\end{abstract}

Key words: Byproducts, disappearance, fruit culture, ruminants, sheep

\section{Resumo}

Objetivou-se neste estudo avaliar a composição quimico - bromatológica e a degradabilidade ruminal da matéria seca (MS), da proteína bruta (PB) e fibra em detergente neutro (FDN) de resíduos da agroindústria de fruta. foram utilizados três ovinos fistulados no rúmen, mantidos em baias coletivas, recebendo diariamente dieta composta de capim canarana (Echinochloa pyramidalis) e concentrado a base de milho e soja e os resíduos estudados. Os animais passaram por período de adaptação de sete dias.

${ }^{1}$ Parte da Dissertação de Mestrado do Programa de Pós-Graduação em Produção Animal do segundo autor.

2 Profs. Drs., Universidade Federal Rural do Semiárido UFERSA, Mossoró, RN, Brasil. E-mail: apbraga@ufersa.edu.br; josemir@ ufersa.edu.br; liz@ufersa.edu.br

${ }^{3}$ Mestres em Produção Animal, Universidade Federal Rural do Semiárido UFERSA, Mossoró, RN, Brasil. E-mail: vilmaamancio@ ufersa.edu.br; isaacsydney10@gmail.com; danillo_gladson@hotmail.com.

${ }^{4}$ Prof $^{\mathrm{a}} \mathrm{Dr}^{\mathrm{a}}$, Curso Técnico de Zootecnia, Instituto Federal de Educação, Ciência e Educação do Rio Grande do Norte, IFRN, Apodi, RN. E-mail: cicilia.silva@ifrn.edu.br

* Author for correspondence 
Os resíduos foram secos ao sol e triturados em peneira de 4,0 mm e incubados nos tempos de 3, 6, 12, $24,48,72$ e 96 horas, utilizando sacos de tecido não tecido de gramatura 60 , nas dimensões de $14 \times 12$ $\mathrm{cm}^{2}$. Foram realizadas as análises químico - bromatologica dos resíduos. O delineamento experimental utilizado foi em blocos ao acaso com parcelas subdivididas. Os resíduos de graviola e tamarindo apresentaram as maiores concentrações de proteína bruta $(12,66$ e $11,79 \%)$, para o teor de extrato etéreo $(22,30 \%)$ destaca-se o resíduo de graviola. Os resíduos de caju e goiaba apresentaram os maiores teores de lignina, (22,13 e 18,34\%). A Degradabilidade efetiva da matéria seca do resíduo de abacaxi e tamarindo, para taxa de passagem de 5\%/h foram de 53,04\% e 42,61\% respectivamente. Já os resíduos de goiaba graviola e caju apresentaram valores inferiores $19,16 \%, 26,86 \%$ e $29,21 \%$ respectivamente. Os resíduos de graviola, goiaba e abacaxi apresentaram maiores valores da degradabilidade potencial para proteína bruta, $87,81 \% ; 86,02 \% ; 90,94 \%$ respectivamente, com média para degradabilidade efetiva de $50,0 \%$ na taxa de $5 \% / \mathrm{h}$. Os resíduos de abacaxi e tamarindo apresentaram maiores valores da degradabilidade efetiva da fibra em detergente neutro $35,38 \%$ e $34,49 \%$ respectivamente, para taxa de passagem de $5 \% / \mathrm{h}$. O resíduo de abacaxi apresentou maior potencial para utilização na alimentação animal em função da composição químico-bromatológica e taxas de degradabilidade.

Palavras-chave: Desaparecimento, fruticultura, ovino, ruminantes, subprodutos

\section{Introduction}

Favorable climatic conditions in conjunction with irrigated agriculture in the Northeast highlight region have enabled the production of tropical fruits such as pineapple, avocado, bananas, cashew, coconut, papaya, mango, passion fruit, grape, acerola, and guava (ANUÁRIO BRASILEIRO DE FRUTICULTURA, 2010). The potential industrialization of the production of these fruits provides great potential for agribusiness that usually results in the accumulation of by-product, thereby affecting the environment (PEREIRA et al., 2013).

Fruit processing generates organic by-products composed of pulp residues, bark, and stones or seeds, and the high levels of fiber may render these by-products suitable (LOUSADA JUNIOR et al., 2006).

The use of fruit processing residues in animal feed can benefit animal diet composition in different regions of Brazil, ensuring, in many cases, greater availability of food and minimizing damage to the environment caused by the decomposition of organic matter (CRUZ et al., 2013). However, it is essential to characterize these foods by determining the chemical composition and availability of nutrients for the animal.
In situ techniques can provide information about the fractions that make up the food, the amount of food degraded, and the degradation rate, accounting for the variety of digestive events occurring in the animal (SANTOS et al., 2012). In addition, knowledge of the kinetics of the rumen generates important information of the digestive processes that best describes the nutritional value for food nutritionist attempting to provide the best care when balancing animal diets (JOBIM et al., 2012). Therefore, the aim of this study was to evaluate the degradability of industrial fruit processing byproducts dry matter $(\mathrm{DM})$, crude protein $(\mathrm{CP})$, and neutral detergent fiber (NDF) as potential for animal feed.

\section{Materials and Methods}

The experiment was conducted at the Center of Studies and Research in Small Ruminants and the Animal Nutrition Laboratory of the Department of Animal Sciences (DCAn) at Universidade Federal Rural do Semiárido (UFERSA). To study the residue degradability of cashew (Anacardium occidentale), guava (Psidium guajava), pineapple (Ananas comosus), cherimoya (Annona muricata), and tamarind (Tamarindus indica), we used three adult male sheep (without a defined breed; not 
castrated) that were fistulated in the rumen. The ration was composed of soybean meal, corn meal, and canarana grass (Echinochloa pyramidalis). There was concern about the small variation of nutrients when balancing the rations due to adaptations of the introduced by-products to new substrate microflora. Throughout the experiment, the animals were maintained in a confinement system in collective stalls that featured a drinking fountain and a trough for mineral mixture. Animals were fed daily in the morning and afternoon. The concentrate and the residues were mixed together in the trough. The animals were adapted to residues for a period of 7 days.

The residues were acquired at a fruit processing company in the city of Mossoro-RN. Residues were spread in thin layers on a cemented area to dry in the sun. Layers were turned at least three times a day. To facilitate the control of humidity, samples were removed during the dehydration process for total dry matter and laboratory analysis. Dehydration was terminated when the by-product reached approximately $85 \%$ of $\mathrm{DM}$, or approximately 5 d later. After drying, samples were crushed in a hammer-type mill, and sorted with a 4.0-mm mesh sieve for incubations and a $1.0-\mathrm{mm}$ mesh sieve for chemical analysis.

Residues varied by the type of fruit used. Pineapple residue consisted of shells and pressed pulp; cherimoya residues were from seeds, bark, and pulp; guava residues were from macerated seeds and pulp; tamarind residues were from the skin, pulp, and seeds; and cashew residues were composed of complete bagasse.

To determine the ruminal degradability of DM, $\mathrm{CP}$, and NDF by-products, non-woven bags (NWB) $60 \mathrm{~g} / \mathrm{m}^{2} ; 14 \times 12 \mathrm{~cm}$ ) were fabricated manually, and closed with a hot sealing machine.

To remove excess moisture, the bags were placed in an oven at $105^{\circ} \mathrm{C}$ on a paper towel-lined tray for $60 \mathrm{~min}$. Bags were then placed in a desiccator, weighed, and a $3.3 \mathrm{~g}$ of DM sample was added to maintain a relationship of around $20 \mathrm{mg} \mathrm{DM} / \mathrm{cm}^{2}$. The water-soluble fraction $a$ corresponding to time zero was determined by placing bags with $3.3 \mathrm{~g}$ of DM sample in a water bath at $39^{\circ} \mathrm{C}$ for $1 \mathrm{~h}$ and then washing them in cold water. Bags were then dried in an air circulation oven for $72 \mathrm{~h}$ at $55^{\circ} \mathrm{C}$, cooled in a desiccator, and weighed on a precision scale. For incubation, bags were impregnated with clean water, attached to a metal chain with a snap-ring (weighing approximately $120 \mathrm{~g}$ ), and inserted into the rumen via the ruminal fistula. Bags were incubated for 3 , $6,12,24,48,72$, and $96 \mathrm{~h}$. The five types of residue were evaluated in triplicate per sheep for each time, totaling fifteen bags per animal per incubation time. At the end of each incubation time, the bags were removed from the rumen and immediately placed for about $10 \mathrm{~min}$ in an ice bucket containing water to stop microbial activity. Subsequently, bags were washed manually in clean running water until the color reduced in intensity and were then dried in an air-circulation oven for $72 \mathrm{~h}$ at $55^{\circ} \mathrm{C}$. The remaining by-product was removed from NWB, ground in a Willey-type mill, and filtered with a 1-mm sieve to determine DM, NDF, and CP. The use of NWB can provide a low-cost alternative to a F57 study that quantifies fibrous indigestible compounds in foods, since it is generally estimated with similar levels of accuracy and precision (CASALI et al., 2009).

The percentage of by-product loss in the rumen for DM, CP, and NDF), was obtained by examining the difference in bag weight before and after incubation. The portion of the sample disappeared from the bag during incubation was considered degraded.

The disappearance curves were fitted to the model proposed by Ørskov and McDonald (1979), according to the following equation: $\mathrm{PD}=\mathrm{a}+\mathrm{b}$ (1- $\mathrm{e}^{-\mathrm{ct}}$ ), where PD is the degradability during the incubation time $(\mathrm{t}) ; a$ is the water soluble fraction; $b$ is the potential degradable fraction in the rumen; $c$ is the degradation rate per hour of fraction $\mathrm{b} ; e^{-c t}$ is the natural logarithm of (-ct); and $t$ is the incubation time in hours. Effective degradability (ED) was 
calculated using the equation: $E D=(a+b+c) /(c+$ $\mathrm{k})$, considering the passage of the ruminal rate of 2 , 5 , and $8 \% / \mathrm{h}$ due to the varying levels of food (i.e., low, medium and high consumption), and where $k$ is the rate of passage.

The experimental design was a randomized block design with split plots, where three animals represented the blocks with five by-product treatments and three replications. The average degradability was compared using Tukey's test and a regression analysis with the level of significance set at 5\%. To perform the statistical analysis we used the SISVAR 5.1 statistical software (FERREIRA, 2011).

\section{Results and Discussion}

The pineapple and guava by-product (Table 1) had lower $\mathrm{CP}$ values $(8.4 \%$ and $8.02 \%$, respectively) than the cherimoya, cashew and tamarind by-product $(12.66 \%, 10.62 \%$ and $11.79 \%$ respectively). These values are above the minimum $7 \%$ of $\mathrm{CP}$ suggested for the occurrence of a good rumen function. According to Silva et al. (2014), it is important to provide the minimum $7 \% \mathrm{CP}$ in the diet to maintain the microbial fermentation activities that occur in the rumen. The cherimoya residue showed the highest amount of ether extract (22.3\%); lower than the $24.46 \%$ reported by Cisne et al. (2006). The chemical composition of agro by-product may vary depending on the mode of fruit processing, shelf life, room temperature, and soil type (SILVA et al., 2014). The NDF of guava, cashew, and pineapple by-products was $69.29 \%$, $62.72 \%, 61.40 \%$, respectively, and was higher than the residue of tamarind and cherimoya $(50.04 \%$ and $46.05 \%$, respectively). Lousada Junior et al. (2006) evaluated fruit by-products for feeding sheep and reported NDFs of $71.39 \%$ for pineapple residue and $73.45 \%$ for guava residue; these values were higher than those observed in this study.

Table 1. Chemical composition of pineapple, cherimoya, guava, cashew, and tamarind by-products.

\begin{tabular}{cccccc}
\hline \multirow{2}{*}{ Nutrients \% } & \multicolumn{5}{c}{ By-product } \\
\cline { 2 - 5 } & Pineapple & Cherimoya & Guava & Cashew & Tamarind \\
\hline DM & 84.70 & 89.94 & 90.80 & 88.90 & 88.95 \\
CP & 8.40 & 12.66 & 8.02 & 10.62 & 1.79 \\
EE & 1.80 & 22.30 & 7.92 & 3.40 & 2.52 \\
NDF & 61.40 & 46.05 & 69.29 & 62.72 & 50.04 \\
ADF & 23.79 & 29.78 & 49.04 & 39.04 & 2.53 \\
HEM & 37.61 & 16.27 & 20.25 & 23.68 & 2.51 \\
CEL & 14.07 & 21.73 & 30.77 & 12.41 & 10.30 \\
LIG & 5.93 & 8.04 & 18.34 & 22.13 & 10.20 \\
CEL & 14.07 & 21.73 & 30.77 & 12.41 & 10.30 \\
NDIN & 0.69 & 1.06 & 0.92 & 2.92 & 2.58 \\
ADIN & 0.45 & 0.38 & 0.25 & 2.62 & 1.74 \\
NFC & 21.63 & 15.15 & 11.08 & 19.07 & 32.98 \\
TCHO & 83.79 & 61.2 & 80.37 & 81.79 & 83.02 \\
\hline
\end{tabular}

DM - Dry matter; CP - Crude protein; EE - Ether extract; NDF - Neutral detergent fiber; ADF - Acid detergent fiber; HEM Hemicelluloses; LIG - Lignin; CEL - Celluloses; NDIN - Neutral detergent insoluble nitrogen; ADIN - Acid detergent insoluble nitrogen; NFC - No fibrous carbohydrates; Total carbohydrates. 
Rogério et al. (2007) studied the nutritional value of fruit by-products for sheep and noted NDF values of $66.14 \%$ and $79.23 \%$ for the pineapple byproduct. Pereira et al. (2008) evaluated cherimoya residue and reported a NDF value of $47.0 \%$, a similar value to the results of this work.

According to Mertens (1997), fiber can be defined nutritionally as the slowly digestible or indigestible portion of food that occupies space in the gastrointestinal tract. In addition, high NDF food intake is negatively correlated with consumption due to slower digestibility and longer retention time in the rumen, causing a filling effect. The values of soluble fraction $a$, the potentially degradable $b$ fraction, and the related rate for non-degradable fraction and potentially degradable fraction $c$ are shown in (Table 2). Among the five by-products studied, pineapple residues showed the highest soluble fraction $a(32.46 \%)$ than all others. The fraction $a$ food represents the soluble fractions that are rapidly and completely degraded in the rumen. Pires et al. (2010) characterizes fraction $a$ food as the solubilization of soluble sugars and nitrogen compounds consisting mainly of sucrose, fructose, and glucose.

Table 2. Potential degradability (PD) and effective degradability (ED) of dry matter (DM) from cashew, guava, pineapple, cherimoya, and tamarind by-products.

\begin{tabular}{cccccc}
\hline \multirow{2}{*}{ Parameters } & \multicolumn{5}{c}{ By-product } \\
\cline { 2 - 6 } & Cashew & Guava & Pineapple & Cherimoya & Tamarind \\
\hline $\mathrm{a} \%$ & 19.01 & 10.31 & 32.46 & 12.05 & 15.82 \\
$\mathrm{~b} \%$ & 32.73 & 21.31 & 49.11 & 55.81 & 65.30 \\
$\mathrm{c} \%$ & 2.3 & 3.6 & 3.7 & 1.8 & 3.5 \\
$\% \mathrm{PD}$ & 51.74 & 31.62 & 80.86 & 67.86 & 81.12 \\
$\% \mathrm{ED}(2 \%)$ & 36.25 & 23.89 & 63.82 & 38.51 & 57.32 \\
$\% \mathrm{ED}(5 \%)$ & 29.21 & 19.16 & 53.04 & 26.86 & 42.61 \\
$\% \mathrm{ED}(8 \%)$ & 26.26 & 16.89 & 47.87 & 22.33 & 35.62 \\
\hline
\end{tabular}

a - soluble fraction; b - potentially degradable fraction; c - degradation rate; \% PD - potential degradability; \% ED - effective degradability.

Guava residues showed the lowest potential degradability (PD) value $(31.62 \%)$, and this correlated with the low value of fraction $b$ (21.31\%), probably due to the high amount of seed in this residue, with associated large acid detergent fiber ADF and lignin concentrations (Table 1).

Cherimoya residues resulted in a fraction $b$ of $55.8 \%$ and a degradation rate of fraction $c$ at 1.8 $\mathrm{h}$, indicating the potential for a slow-degrading source in the rumen. It should be noted that chemical analysis of the cherimoya residue (Table 1) revealed a higher ether extract content (22.3\%), indicating high fat content, which according to Rufino et al. (2010), can limit DM intake and alter ruminal fermentation, thereby adversely affecting the breakdown of food.

The tamarind by-product had a potential degradability of DM of $81.1 \%$. This is probably related to the high value of the potentially degradable fraction (fraction $b$ ) and the high content of non-fibrous carbohydrates of this byproduct.

The most effective degradation was observed for the pineapple residue $(63.82 \%$ at $2 \% / \mathrm{h}$; $53.04 \%$ at $5 \% / \mathrm{h}$; and $47.87 \%$ at $8 \% / \mathrm{h}$ ), the lower lignin and ADF values allowed this residue to split $a$ and $b$ apart. 
The cherimoya residues had EDs for DM of $38.51 \%(2 \% / \mathrm{h}), 26.89 \%(5 \% / \mathrm{h})$, and $22.33 \%(8 \% / \mathrm{h})$ (Table 2).

Guava and cashew residues had the lowest values for ED of dry matter at $23.89 \%(2 \% / \mathrm{h}), 19.20 \%$ $(5 \% / \mathrm{h})$, and $16.98 \%(8 \% / \mathrm{h})$ for guava, and $36.25 \%$ $(2 \% / \mathrm{h}), 29.21 \%(5 \% / \mathrm{h})$, and $26.26 \%(8 \% / \mathrm{h})$ for cashew. These residues had high lignin contents. Lignin acts as a barrier restricting the activities of digestive enzymes produced by the microorganisms of the rumen and consequently decreasing the degradability and digestibility (OLIVEIRA et al., 2013).

The disappearance of DM by-product increased with the duration of ruminal incubation (Table 3 ).
This was expected, as the residue that remained in the rumen longer endured more prolonged microbial action. According to Uchoa et al. (2008), the disappearance of the DM in the by-product begins after 3 hours, because fruits rich in sugars (glucose and fructose) have a high potential for fermentation.

The pineapple by-product DM disappearance curve (Figure 1) was higher than others by-products studied until the last time of evaluation (96h), when the cashew by-product disappearance became similar. This may be associated with the lower pineapple by-product lignin concentration, which promoted higher pineapple by-product effective degradabilities (Table 2). This is an important characteristic because it is related with rumen faster emptying and nutrients consumption increase.

Figure 1. Disappearance curve for of dry matter (DM) of the by-products as a function of incubation time.

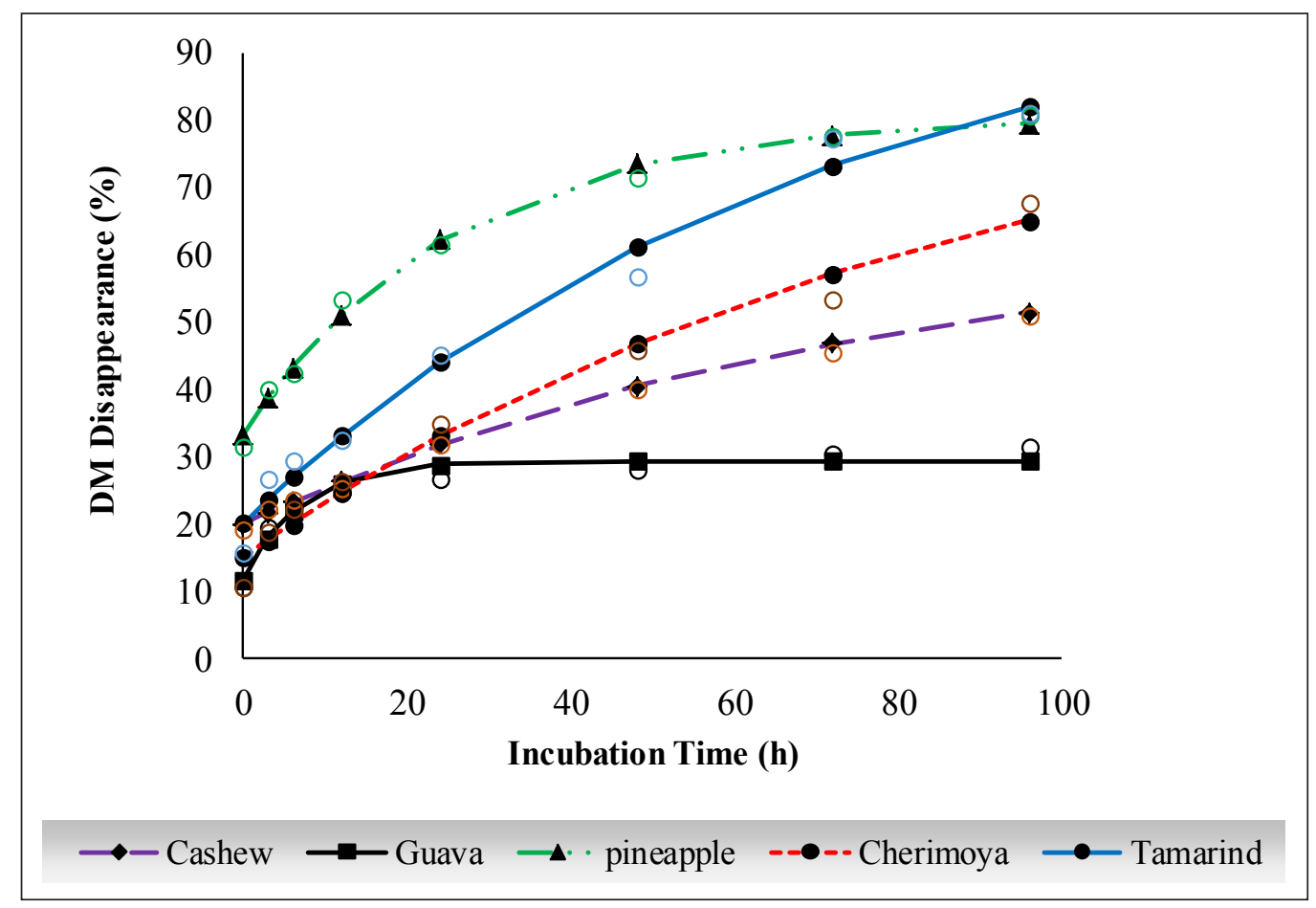

The tamarind residue values for fraction $a$ were an exception, with CP being below 30\%, suggesting relatively low amounts of soluble protein (Table 4).
The cashew residue showed the lowest value (41.8\%) for the potentially degradable CP fraction in the rumen, followed by tamarind residues at $48.6 \%$. This is verified by the high acid detergent 
insoluble nitrogen (ADIN), neutral detergent in these residues, these being the nitrogen fraction insoluble nitrogen NDIN and lignin concentrations unavailable to the microbes (Table 1).

Table 3. Disappearance of dry matter depending on incubation times for the by-products of cashew, cherimoya, pineapple, guava, and tamarind.

\begin{tabular}{cccccc}
\hline \multirow{2}{*}{ Time } & \multicolumn{5}{c}{ DMS } \\
\cline { 2 - 5 } & Cashew & Guava & Pineapple & Cherimoya & Tamarind \\
\hline 0 & $19.01 \mathrm{~Gb}$ & $10.31 \mathrm{Gd}$ & $31.46 \mathrm{Ga}$ & $12.05 \mathrm{Hd}$ & $15.89 \mathrm{Hc}$ \\
3 & $22.47 \mathrm{Fc}$ & $19.46 \mathrm{Fd}$ & $40.14 \mathrm{Fa}$ & $18.81 \mathrm{Gd}$ & $26.67 \mathrm{~Gb}$ \\
6 & $23.67 \mathrm{EFc}$ & $22.58 \mathrm{Ec}$ & $42.43 \mathrm{Fa}$ & $22.19 \mathrm{Fc}$ & $29.36 \mathrm{Fb}$ \\
12 & $25.27 \mathrm{Ec}$ & $24.77 \mathrm{DEc}$ & $53.26 \mathrm{Ea}$ & $26.28 \mathrm{Ec}$ & $32.64 \mathrm{~Eb}$ \\
24 & $31.78 \mathrm{Dd}$ & $26.78 \mathrm{CDe}$ & $61.80 \mathrm{Da}$ & $34.79 \mathrm{Dc}$ & $45.23 \mathrm{Db}$ \\
48 & $40.19 \mathrm{Cd}$ & $28.27 \mathrm{BCe}$ & $71.38 \mathrm{Ca}$ & $45.96 \mathrm{Cc}$ & $56.79 \mathrm{Cb}$ \\
72 & $45.47 \mathrm{Bc}$ & $30.54 \mathrm{ABd}$ & $77.67 \mathrm{Ba}$ & $53.33 \mathrm{Bb}$ & $77.34 \mathrm{Ba}$ \\
96 & $50.96 \mathrm{Ac}$ & $31.62 \mathrm{Ad}$ & $80.86 \mathrm{Aa}$ & $67.86 \mathrm{Ab}$ & $81.12 \mathrm{Aa}$ \\
\hline
\end{tabular}

Means followed by the same lowercase letter on the line and the same capital letter in the column are statistically similar (Tukey's test; $\mathrm{P}>0.05)$.

Table 4. Potential degradability (PD) and effective degradability (ED) of crude protein from cashew, guava, pineapple, cherimoya, and tamarind by-products.

\begin{tabular}{cccccc}
\hline \multirow{2}{*}{ Parameters } & \multicolumn{5}{c}{ By-product } \\
\cline { 2 - 6 } & Cashew & Guava & Pineapple & Cherimoya & Tamarind \\
\hline $\mathrm{a} \%$ & 10.55 & 23.47 & 17.87 & 13.90 & 31.75 \\
$\mathrm{~b} \%$ & 41.99 & 62.55 & 73.06 & 74.73 & 48.64 \\
$\mathrm{c} \%$ & 2.7 & 3.7 & 3.7 & 2.8 & 3.3 \\
$\% \mathrm{PD}$ & 51.53 & 86.02 & 90.94 & 87.81 & 80.39 \\
$\% \mathrm{ED}(2 \%)$ & 34.05 & 63.53 & 65.84 & 56.84 & 61.73 \\
$\% \mathrm{ED}(5 \%)$ & 24.75 & 49.61 & 49.53 & 39.91 & 50.87 \\
$\% \mathrm{ED}(8 \%)$ & 20.86 & 42.84 & 41.50 & 31.61 & 46.81 \\
\hline
\end{tabular}

a - soluble fraction; $b$ - potentially degradable fraction; c- degradation rate of fraction b, \% PD - potential degradability; \% ED effective degradability.

Guava and pineapple by-products showed a potentially degradable fraction of $62.55 \%$ and $73.06 \%$, with degradation rates of $c$ greater than those of the others (i.e., 3.7\%/h). The chemical composition in the residue of guava contained higher lignin e ADF content (Table 1). These parameters could hinder microbial attacks, potentially leading to lesser degradability. However, this residue had low proportions of ADIN and NDIN (Table 1), indicating the high availability of nitrogen for rumen microorganisms.

The residue of cherimoya showed a high value (74.4\%) for the fraction $b$, suggesting a source of rumen degradable protein, but with a slow degradation rate $(2.8 \% / \mathrm{h})$.

The potential and effective degradability of protein was lower for the cashew residue than for the other residues,. This is confirmed by the fact that the cashew residue had the smallest fraction 
of $a$ and $b$ (10.55\% and $41.8 \%$, respectively) and comparatively high levels of ADF, lignin, NDIN and ADIN (Table 1), as these parameters have a direct influence on ruminal degradability of protein.

The greatest potential degradability (PD) of protein was observed in the pineapple residue (90.94\%). This can be attributed to its high fraction $b$, degradation rate $c$, and the low concentration of the lignified fraction (Table 1). The by-products had relatively high $\mathrm{CP}$ content ranging from $8.02 \%$ for the guava to $12.66 \%$ for the cherimoya residue. High levels of $\mathrm{CP}$ associated with high effective degradability of CP may be indicative of synchronism between the fermentation of protein and carbohydrates for maximum microbial synthesis (GOES et al., 2012).

Residues differed for the disappearance of crude protein at time zero $(\mathrm{P}<0.05$; Table 5$)$. The tamarind residue had the highest disappearance at $31.75 \%$, followed by guava residue at $23.07 \%$, pineapple at $17.0 \%, 29.0 \%$ and $13.73 \%$, and cherimoya and cashew at $10.55 \%$.

Table 5. Loss of crude protein from cashew, cherimoya, pineapple, guava, and tamarind by-products.

\begin{tabular}{cccccc}
\hline \multirow{2}{*}{ Time } & \multicolumn{5}{c}{ DPB } \\
\cline { 2 - 5 } & Cashew & Guava & Pineapple & Cherimoya & Tamarind \\
\hline 0 & $10.55 \mathrm{He}$ & $23.47 \mathrm{~Gb}$ & $17.87 \mathrm{Hc}$ & $13.90 \mathrm{Hd}$ & $31.75 \mathrm{Fa}$ \\
3 & $25.92 \mathrm{Gd}$ & $41.51 \mathrm{Fb}$ & $45.34 \mathrm{Ga}$ & $30.58 \mathrm{Gc}$ & $31.81 \mathrm{FGc}$ \\
6 & $28.33 \mathrm{Fe}$ & $61.58 \mathrm{Ea}$ & $58.49 \mathrm{Fb}$ & $45.39 \mathrm{Fc}$ & $33.76 \mathrm{Fd}$ \\
12 & $31.70 \mathrm{Ee}$ & $69.81 \mathrm{Db}$ & $73.50 \mathrm{Ea}$ & $54.87 \mathrm{Ec}$ & $38.34 \mathrm{Ed}$ \\
24 & $37.30 \mathrm{De}$ & $76.16 \mathrm{Cb}$ & $81.28 \mathrm{Da}$ & $65.75 \mathrm{Dc}$ & $43.72 \mathrm{Dd}$ \\
48 & $43.14 \mathrm{Ce}$ & $80.00 \mathrm{Bb}$ & $84.69 \mathrm{Ca}$ & $74.75 \mathrm{Cc}$ & $57.54 \mathrm{Cd}$ \\
72 & $46.96 \mathrm{Be}$ & $82.19 \mathrm{Bb}$ & $87.34 \mathrm{Ba}$ & $79.25 \mathrm{Bc}$ & $76.26 \mathrm{Bd}$ \\
96 & $51.53 \mathrm{Ad}$ & $86.02 \mathrm{Ab}$ & $90.94 \mathrm{Aa}$ & $87.81 \mathrm{Ab}$ & $81.27 \mathrm{Ac}$ \\
\hline
\end{tabular}

Means followed by the same lowercase letter on the line and the same capital letter in the column are statistically similar (Tukey's test; $\mathrm{P}>0.05)$.

The disappearance of guava residue protein after $6 \mathrm{~h}$ of incubation was higher than the other residues; however, the disappearance of crude protein was superior to pineapple residue after 12 h. (Table 5). This can be explained by the heterogeneity of the guava residue, which was composed of pulp and seeds. Milling these seeds generated a fraction with low viscosity, which probably corresponded to the highly fermentable pulp and other intact seeds, which are resistant to microbial activity. The initial microbial attack on the finest-grained fraction may have increased the disappearance of the protein, but over time, the microorganism probably had greater difficulty degrading this material due to the high lignin content in this by-product.

For the pineapple residue, more than $70 \% \mathrm{CP}$ had disappeared after $12 \mathrm{~h}$; this disappearance was superior to that of the other residues. Carvalho et al. (2009) suggested that by-products with a high potential for degradation could be lowcost alternatives offering quickly and abundantly available nutrients to the ruminal system.

Cashew and tamarind residues showed the lowest CP disappearance $(31.70 \%$ and $38.34 \%$, respectively) after $12 \mathrm{~h}$ (Table 5). The disappearance of the remaining residues at the same time frame was less than $50 \%$, demonstrating greater availability of this nutrient from cashew and tamarind residues 
for ruminal microorganisms. The disappearance of cashew residues after $96 \mathrm{~h}$ was $51.53 \%$. This was low compared to the disappearance of the other residue proteins at the same time frame $(>80 \%)$.

The contents of NDIN and ADIN in relation to other residue by-products are associated with high lignin content, indicating that part of the nitrogen is unavailable for rumen microorganisms, thus interfering in the degradability of the protein.
The disappearance of the curve behavior of crude protein from cashew, guava, pineapple, cherimoya and tamarind can be seen in (Figure 2). The disappearance curve of protein for pineapple residue was superior to the others; $24 \mathrm{~h}$ incubation showed over $80 \%$ disappearance of CP (Table 5). This behavior is important because the high degradation rate coupled with the other parameters indicates that the protein of this by-product is responsible for fast ruminal degradation.

Figure 2. Disappearance curve for crude protein (CP) from the by-products as a function of incubation time.

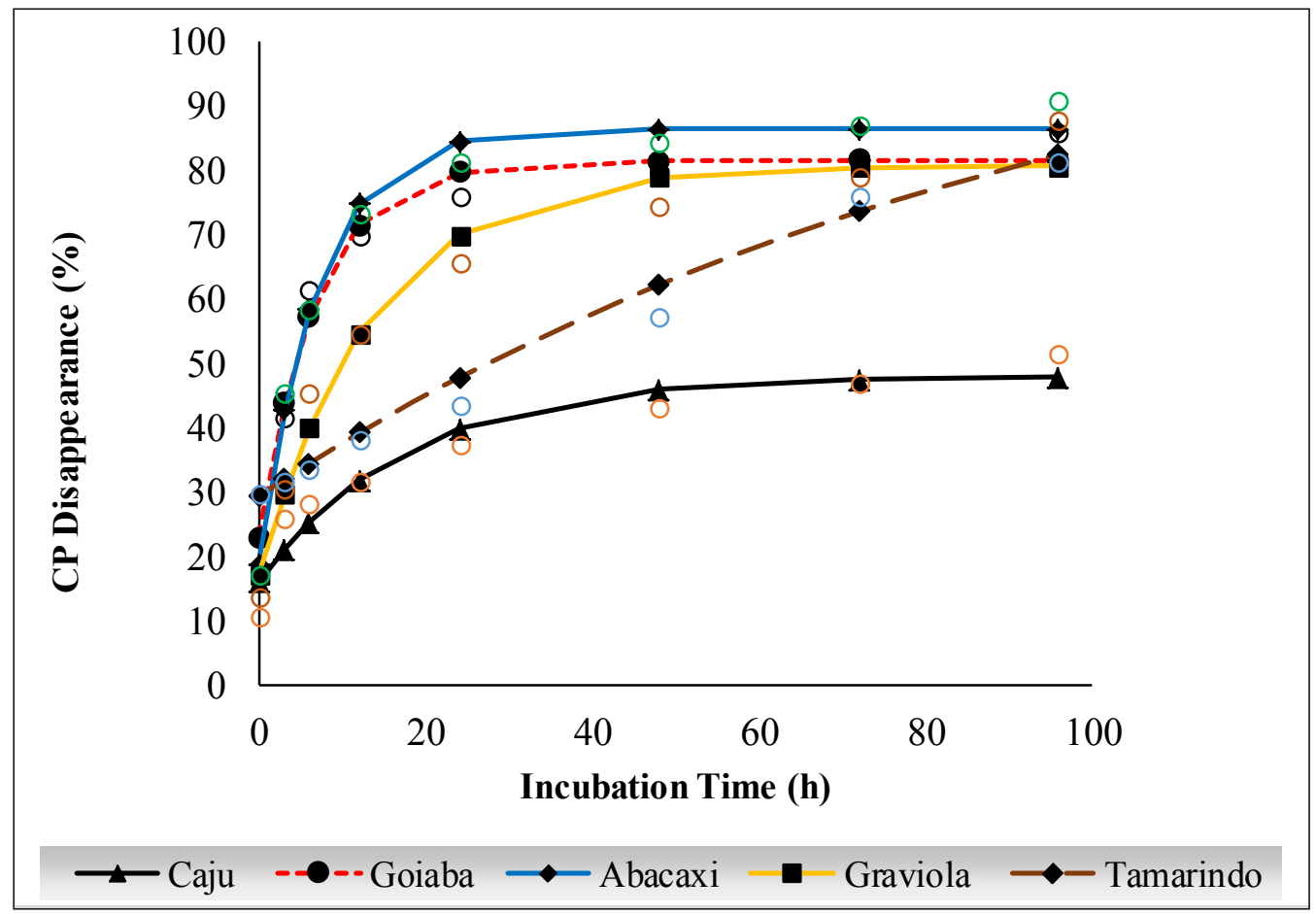

The disappearance curves of pineapple, cherimoya, guava and cashew by-products showed a tendency to stabilize in order to reach the maximum degradation point (Figure 2; Table 5). Note that the protein residues after 72 and $96 \mathrm{~h}$ continues to disappear, requiring a longer time than those studied in this work to reach its maximum degradation. There has been a growing trend in the disappearance of tamarind residue, demonstrating a need to continue long-term studies in this work.
The values of fraction $a$, of potentially degradable fraction $b$, and the degradation rate of potentially degradable fraction $c$ of fruit residue NDF is shown in (Table 5). The soluble fraction of NDF was 9.74\%, $8.79 \%, 7.43 \%, 4.34 \%$, and $3.95 \%$, for cherimoya, pineapple, guava, cashew, and tamarind residues, respectively. As for the potentially degradable fraction of NDF, the residue of tamarind presented the highest value $(71.46 \%)$, with a degradation rate of $3.7 \% /$ h. (Table 6 ). 
Table 6. Ruminal degradation parameters, potential degradability (PD), and effective degradability (ED) of the neutral detergent fiber (NDF) of various by-products.

\begin{tabular}{cccccc}
\hline \multirow{2}{*}{ Parameters } & \multicolumn{5}{c}{ By-product } \\
\cline { 2 - 6 } & Cashew & Guava & Pineapple & Cherimoya & Tamarind \\
\hline $\mathrm{a} \%$ & 4.34 & 7.43 & 8.79 & 9.74 & 3.95 \\
$\mathrm{~b} \%$ & 38.17 & 19.85 & 64.27 & 50.62 & 71.46 \\
$\mathrm{c} \%$ & 1.4 & 3.3 & 3.7 & 1.5 & 3.7 \\
$\% \mathrm{PD}$ & 42.51 & 27.28 & 72.57 & 60.36 & 75.41 \\
$\% \mathrm{ED}(2 \%)$ & 20.09 & 19.30 & 49.70 & 31.00 & 50.45 \\
$\% \mathrm{ED}(5 \%)$ & 12.68 & 16.62 & 35.38 & 21.12 & 34.49 \\
$\% \mathrm{ED}(8 \%)$ & 9.71 & 13.96 & 28.44 & 17.51 & 26.69 \\
\hline
\end{tabular}

a - soluble fraction; $\mathrm{b}$ - potentially degradable fraction; $\mathrm{c}$ - degradation rate of fraction $\mathrm{b}, \% \mathrm{DP}$ - degradability potential; \% DE effective degradability.

The pineapple residue had a potentially degraded fraction of $64.27 \%$ at a rate of $3.7 \% / \mathrm{h}$ for $c$. This was greater than the cherimoya, guava, and cashew by-products and is attributed to the lower lignin content (Table 1) of this residue in relation to the residues of cherimoya, guava, and cashews.

The lowest rate of degradation was from the cashew residue $(1.4 \% / \mathrm{h})$, and is attributed to the high lignin content because the lignin acts as a mechanical barrier inhibiting microbial action (VAN SOEST, 1994). According to Sampaio (1998), food with a degradation rate of less than $2 \%$ /h is lowquality food that requires longer exposure to the ruminal environment to be degraded.

The value of $b$ fraction for cherimoya residue was $50.6 \%$ and had a $1.4 \% / \mathrm{h}$ disappearance rate. Lipids are organic substances (i.e., energy suppliers) that may be included in the animal's diet to increase the energy concentration; however, it is not recommended for ruminant diets to contain more than $7 \%$ lipids because of the negative fermentation effect and the fiber degradation of the rumen (SANTOS et al., 2010). Guava residue showed the lowest value for fraction $b$, followed by cashew residue (Table 6 ). This can be explained by the ADF levels in guava (49.04\%) and cashew residues $(39.04 \%)$. The potential degradation and effective degradability resulted in the passage rates of $2.0 \% / \mathrm{h}, 5.0 \% / \mathrm{h}$, and $8 \% / \mathrm{h}$ of NDF by-products (Table 6). There was less potential degradability guava and cashew NDF compared to the other by-products. This degradability occurred with the potential degradation of DM (Table 2), thus showing the relationship between the degradation of DM and NDF. The chemical composition in guava and cashew residues contained higher levels of ADF (Table 1 ). The degradability of the NDF at a passage rate of $2 \% / \mathrm{h}$ for the tamarind residue was superior to that of the pineapple residue for the same time period. However, the degradability of pineapple residue was higher at a rate of $5 \% / \mathrm{h}$ and $8 \% / \mathrm{h}$. A higher pass rate $(5 \% / \mathrm{h}$ and $8 \% / \mathrm{h})$ probably favored the pineapple residue due to its high fractional rate $c$ and soluble fraction $b$.

The fraction of the degradation rates of NDF potentially degraded the by-products; pineapple and tamarind had higher values (Table 6). According to Sarti et al. (2005), the rate of fermentation influences the time that the digestible fraction spends in the rumen. Therefore, the more degradable the NDF content is, the faster its passage and greater the consumption (MENEZES et al., 2012). 
The disappearance of cashew, cherimoya, pineapple, guava, and tamarind NDF is shown in Table 7. The disappearance of pineapple, cherimoya, and guava by-products did not statistically differ from each other at time zero, resulting in similar solubility values $(\mathrm{p}>0.05)$. Cashew and tamarind residues also were not statistically different $(\mathrm{p}>$ $0.05)$.

Among the studied by-products, pineapple and tamarind showed greater extent of disappearance of NDF, with values above $50 \%$ within 48 h. However, after $72 \mathrm{~h}$, tamarind residues obtained the highest disappearance of NDF. The residue of cashew and guava showed the lowest disappearance of NDF at $42.51 \%$ and $27.28 \%$ after $96 \mathrm{~h}$, respectively. Most fibrous by-products with high contents of lignin require attention when added to the diet due to the low digestibility, thus influencing the consumption of MS due to the limitation of ruminal buffering capacity. Mertens (1997) stated that rumen filler is the limiting factor of food intake. The intake of food is negatively related with NDF and the less degradable the residue, the greater the residence time in the rumen.

Table 7. Disappearance of neutral detergent fibers from cashew, cherimoya, pineapple, guava, and tamarind byproducts.

\begin{tabular}{cclccc}
\hline \multirow{2}{*}{ Tempos } & \multicolumn{5}{c}{ DFDN } \\
\cline { 2 - 5 } & Cashew & Guava & Pineapple & Cherimoya & Tamarind \\
\hline 0 & $4.34 \mathrm{~Gb}$ & $7.43 \mathrm{Fa}$ & $8.14 \mathrm{Ha}$ & $9.35 \mathrm{Ha}$ & $3.91 \mathrm{~Gb}$ \\
3 & $16.93 \mathrm{Fb}$ & $11.47 \mathrm{EFc}$ & $13.97 \mathrm{Gc}$ & $23.39 \mathrm{Ga}$ & $22.10 \mathrm{Fa}$ \\
6 & $19.68 \mathrm{EFc}$ & $17.70 \mathrm{Dcd}$ & $21.07 \mathrm{Fc}$ & $30.09 \mathrm{Fa}$ & $24.88 \mathrm{EFb}$ \\
12 & $21.12 \mathrm{DEd}$ & $20.35 \mathrm{CDc}$ & $37.21 \mathrm{Ea}$ & $34.02 \mathrm{~Eb}$ & $27.57 \mathrm{Ec}$ \\
24 & $23.64 \mathrm{Dc}$ & $20.74 \mathrm{Cc}$ & $47.46 \mathrm{Da}$ & $37.79 \mathrm{Db}$ & $46.67 \mathrm{Da}$ \\
48 & $28.21 \mathrm{Cc}$ & $22.99 \mathrm{BCd}$ & $59.16 \mathrm{Ca}$ & $43.45 \mathrm{Cb}$ & $58.39 \mathrm{Ca}$ \\
72 & $31.57 \mathrm{Bd}$ & $25.42 \mathrm{ABe}$ & $68.01 \mathrm{Bb}$ & $49.57 \mathrm{Bc}$ & $71.66 \mathrm{Ba}$ \\
96 & $42.51 \mathrm{Ac}$ & $27.28 \mathrm{Ad}$ & $72.57 \mathrm{Aa}$ & $55.75 \mathrm{Ab}$ & $75.13 \mathrm{Aa}$ \\
\hline
\end{tabular}

Means followed by the same lowercase letter on the line and the same capital letter in the column are statistically similar (Tukey's test; P > 0.05).

The NDF disappearance curve for the byproducts incubated in the rumen is shown in Figure 3. Among the curve behavior, we can see a trend toward greater disappearance of NDF initially for the pineapple residue, but after $48 \mathrm{~h}$, there is an increase in the disappearance of tamarind probably due to the greater degradability value of $72.42 \%$ (Table 7). 
Figure 3. Disappearance curve for neutral detergent fibers (NDF) from the by-products as a function of incubation time.

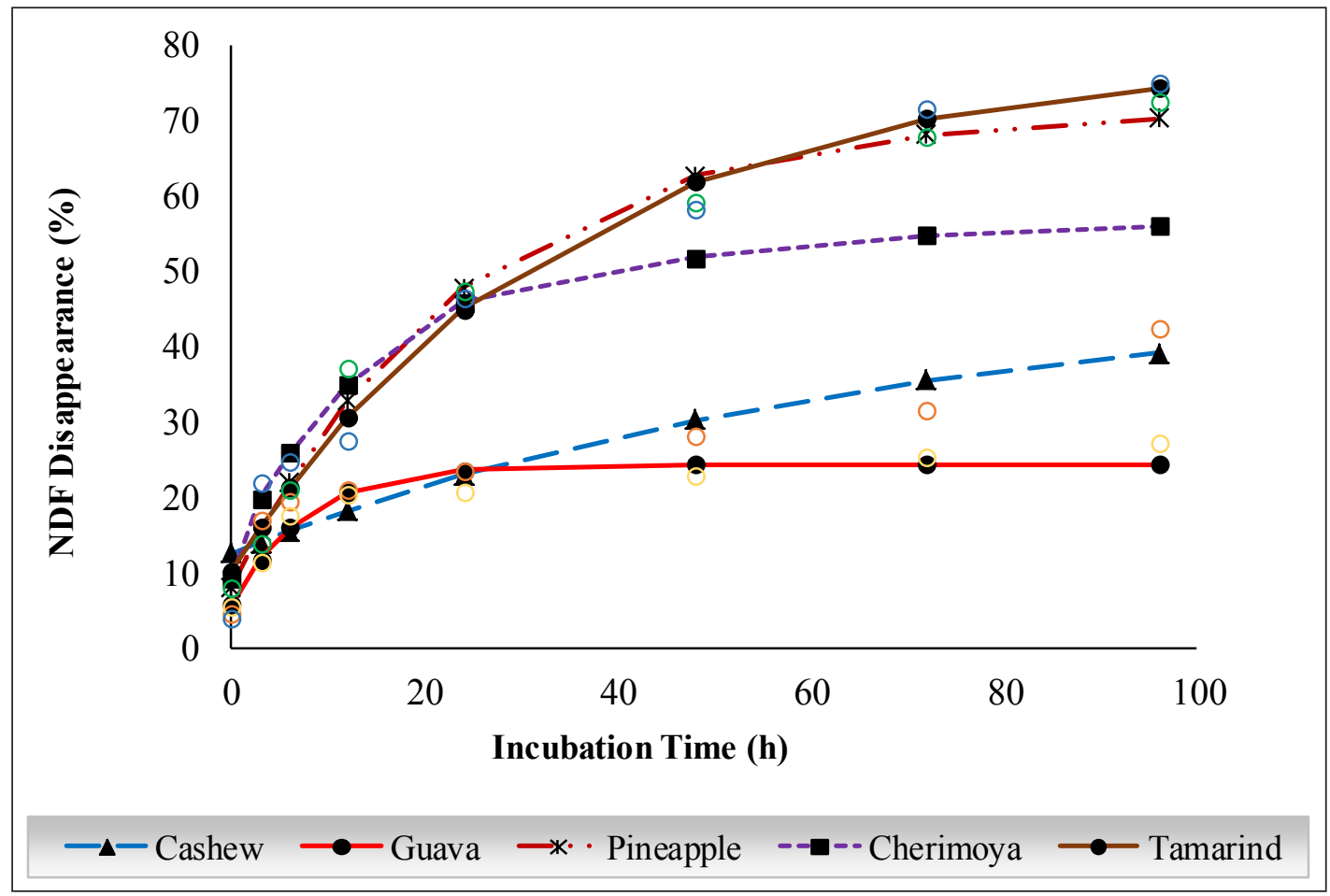

The disappearance curves of guava and cherimoya (Figure 3) showed a tendency to stabilize to achieve the maximum point of degradation; however, the NDF of these residues after 72 and $96 \mathrm{~h}$ continues to disappear (Table 7), requiring a longer time to reach its maximum degradation than those studied in this work. The pineapple, tamarind, and cashew residues showed a stronger tendency to disappear, demonstrating necessity to increase the time duration studied in this work.

\section{Conclusions}

The by-products of pineapple, tamarind, and cherimoya presented better coefficients of potential and effective degradability of DM and NDF in the rumen than did those of cashew and guava residues. The pineapple residue showed desirable potential due to its chemical composition and potential and effective degradability rates. Cashew and guava residues showed high lignin content and had lower
DM and NDF degradability rates, suggesting less potential for use in animal feed than other by-products, such as pineapples, tamarind and cherimoya.

\section{References}

ANUÁRIO BRASILEIRO DE FRUTICULTURA. Santa Cruz do Sul: Editora Gazeta, 2010. 129 p.

CARVALHO, G. G. P.; PIRES, A. J. V.; GARCIA, R.; VELOSO, C. M.; SILVA, R. R.; MENDES, F. B. L.; PINHEIRO, A. A.; SOUZA, D. R. Degradabilidade in situ da matéria seca, proteína bruta e da fração fibrosa de concentrado e subproduto agroindustriais. Ciência Animal Brasileira, Goiânia, v. 10, n. 3, p. 689-697, 2009.

CASALI, A. D.; DETMANN, E.; VALADARES FILHO, S. C.; PERREIRA, J. C.; CUNHA, M.; DETEMANN, K. S. C.; PAULINO, M. F. Estimação de teores de componentes fibrosos em alimentos para ruminantes em sacos de diferentes tecidos. Revista Brasileira de Zootecnia, Viçosa, MG, v. 38, n. 1, p. 130-138, 2009. 
CRUZ, S. S.; MORAIS, A. B. F.; RIBEIRO, S. B.; OLIVEIRA, M. G.; COSTA, M. S.; FEITOSA, C. T. L. Resíduos de frutas na alimentação de ruminantes. Revista Eletrônica Nutritime, Marabá, v. 10, n. 6, p. 2932-2924, 2013.

FERREIRA, D. F. SISVAR: a computer statistical analysis system. Ciência e Agrotecnologia, Lavras, v. 35, n. 6, p. 1039-1042, 2011.

GOES, R. H. T. B.; TRAMONTINI, R. C. M.; CARDIM, S. T.; ALMEIDA, G. D.; RIBEIRO, J.; MOROTTI, F; OLIVEIRA, A. L.; BRADES, K. C. S. Degradação ruminal da matéria seca e da proteína bruta de volumosos para bovino. Revista Acadêmica de Ciências Agrárias e Ambiental, Curitiba, v. 10, n. 3, p. 285-291, 2012.

JOBIM, C. C.; FERREIRA, G. A.; BUMBIERIS JUNIOR, V. H.; CALIXTO JUNIOR, M.; SANTOS, G. T. Cinética de degradação ruminal dos fenos de alfafas, Tifiton-85 e da silagem de milho. Semina: Ciências Agrárias, Londrina, v. 32, n. 2, p. 747-758, 2011.

LOUSADA JUNIOR, J. E.; COSTA, J. M. C.; NEIVA, J. N. M.; RODRIGUES, N. M. Caracterização físico-química de subprodutos obtidos do processamento de frutas tropicais visando seu aproveitamento na alimentação animal. Revista Ciência Agronômica, Fortaleza, v. 37, n. 1, p. 70-76, 2006.

MENEZES, D. R.; PERREIRA, L. G. R.; ARAUJO, G. G. L.; CHAGAS, E. C. O.; RODRIGUES, R. T. S. Cinética da degradação de frações nutricionais de euforbiáceas. Revista Brasileira de Saúde e Produção Animal, Salvador, v. 13, n. 2, p. 424-434, 2012.

MERTENS, D. R. Creating a system for meeting the fiber requirements of dairy cows. Journal of Dairy Science, Madison, v. 80, n. 7, p. 1463-1481, 1997.

OLIVEIRA, E. R.; MONÇÃO, F. P.; GÓES, R. H. T. B.; GABRIEL, A. M. A.; MOURA, L. V.; LEMPP, B.; GRACIANO, D. E.; TACHETTO, A. T. C. Degradação ruminal da fibra em detergente neutro de gramínea do gênero Cynodon spp. em quatro idades de corte. Revista Agrarian, Dourados, v. 6, n. 20, p. 205-214, 2013.
ØRSKOV, E. R.; McDONALD, I. The estimation of protein degradabily in the rumen from incubation measurements weighted according to rate passage. Journal of Agricultural Science, Cambridge, v. 92, n. 2, p. 499-503, 1979.

PEREIRA, C. T. M.; SILVA, C. R. P.; LIMA, A.; PERREIRA, D. M.; COSTA, C. N.; CAVALCANTE NETO, A. A. Obtenção, caracterização física química e avaliação da capacidade antioxidante in vitro da farinha de resíduo de acerola (Malpighia glabra L). Acta Tecnológica, Maranhão, v. 8, n. 2, p. 50-56, 2013.

PEREIRA, L. G. R.; BARREIROS, D. C.; OLIVEIRA, L. S.; FERREIRA, A. L.; MAURÍCIO, R. M.; AZEVEDO, J. A. G.; FIGUEIREDO, M. P.; SOUZA, L. F.; CRUZ, P. G. Composição química e cinética de fermentação ruminal de subprodutos de frutas no Sul da Bahia - Brasil. Livestock Research for Rural Development, Cali, v. 20, n. 1, p. 1-11, 2008.

PIRES, A. J. V.; REIS, R. A.; CARVALHO, G. G. P.; SIQUEIRA, G. R.; BERNARDES, T. F.; RUAGGIERI, A. C.; ROTH, M. T. A. Degradabilidade ruminal da matéria seca, da proteína bruta, e da fração fibrosa de silagens de milho, de sorgo e de Brachiaria Brizanta. Arquivo Brasileiro de Zootecnia, Belo Horizonte, MG, v. 62, n. 2, p. 391-400, 2010.

ROGÉRIO, M. C. P.; BORGES, I.; NEIVA, J. N. M.; RODRIGUES, N. M.; PIMENTEL, J. C. M.; MARTINS, G. A.; RIBEIRO, T. P.; COSTA, J. B.; SANTOS, S. F.; CARVALHO, F. C. Valor nutritivo de resíduo da indústria processadora do abacaxi (Ananas Comossus L.) em dieta para ovinos. 1. Consumo, digestibilidade aparente e balanços energético e nitrogenado. Arquivo Brasileiro de Medicina Veterinária e Zootecnia, Belo Horizonte, v. 59, n. 3, p. 773-781, 2007.

RUFINO, L. M. A.; BARRETO, S. M. P.; DUARTE, E. R.; GERASEEV, L. C.; SANTOS, A. C. R.; JARUCHE, Y. G. Efeito da inclusão de torta de macaúba sobre a população de protozoárias ruminais de caprinos. Revista Brasileira de Zootecnia, Viçosa, MG, v. 40, n. 4, p. 899-903, 2014. 
SAMPAIO, I. B. M. Estatística aplicada à experimentação animal. Belo Horizonte: Fundação de Ensino e Pesquisa em Medicina Veterinária e Zootecnia, 1998. $221 \mathrm{p}$.

SANTOS, J.W.;CABRAL,L. S.;ZERVOUDAKIS, J. T.; ABREU, J. G.; SOUZA, A. L.; PERREIRA, G. B. C.; REVERDITO, R. Farelo de arroz em dieta para ovino. Revista Brasileira de Saúde e Produção Animal, Salvador, v. 11, n. 1, p. 193-201, 2010.

SANTOS, V. C.; EZEQUIEL, J. M. B.; MORGADO, E. S.; HOMEM JUNIOR, A. C.; FÁVARO, V. R.; AUREA, A. P. D.; SOUZA, S. F.; BARBOSA, J. C. Influência de subprodutos de oleaginosas sobre parâmetros ruminais e a degradação da matéria seca e da proteína bruta. Arquivo Brasileiro de Medicina Veterinária $e$ Zootecnia, Belo Horizonte, v. 64, n. 5, p. 12841291, 2012.
SARTI, L. L.; JOBIM, C. C.; BRANCO, A. F.; JACOBS, F. Degradação ruminal da matéria seca, da proteína bruta e da fração fibra de silagens de milho e de capim-elefante. Ciência Animal Brasileira, Goiânia, v. 6, n. 1, p. 1-10, 2005.

SILVA, A. M.; OLIVEIRA, R. L.; RIBEIRO, O. L.; BAGALDO, A. R.; BEZERRA, L. R.; CARVALHO, S. T.; ABREU, C. L.; LEÃO, A. G. Valor nutricional de resíduo da agroindústria para alimentação de ruminantes. Comunicata Scientiae, Bom Jesus, v. 5, n. 4, p. 370-379, 2014.

UCHOA, A. M. A.; COSTA, M. C.; MARIO, G. A.; ELIZABETH, M. C. S.; CARVALHO, A. F. F.V.; MEIRA, T. R. V. Parâmetros físicos e químicos, teor de fibra bruta e alimentar de pós alimentícios obtidos de resíduos de frutas. Revista de Segurança Alimentar e Nutrição, Campinas, v. 15, n. 2, p. 5865, 2008.

VAN SOEST, P. J. Nutritional ecology of the ruminant. 2. ed. Ithaca: Cornell University Press, 1994. 476 p. 